\title{
Penambahan Gula pada Medium Biakan untuk Meningkatkan Pertumbuhan dan Kemampuan Antagonisme Candida tropicalis terhadap Patogen Penyebab Penyakit Layu Fusarium Tomat
}

\author{
Sri Hartati ${ }^{1^{*}}$, Timotius A. Sumbari ${ }^{2}$, Ceppy Nasahi ${ }^{1}$, dan Wawan Kurniawan ${ }^{1}$ \\ ${ }^{1}$ Departemen Hama dan Penyakit Tumbuhan, Fakultas Pertanian, Universitas Padjadjaran \\ Jl. Raya Bandung-Sumedang KM 21, Jatinangor, Indonesia 45363 \\ ${ }^{2}$ Program Studi Agroteknologi, Fakultas Pertanian, Universitas Padjadjaran \\ *Alamat korespondensi: s.hartati@unpad.ac.id
}

\begin{abstract}
Addition of Sugars into Growth Medium to Increase the In Vitro Growth and Antagonism of Candida tropicalis against Fusarium Wilt Pathogen of tomato
\end{abstract}

Fusarium wilt caused by Fusarium oxysporum f.sp. lycopersici (FOL) is one of the major diseases on tomato. Candida tropicalis yeast was proven to be antagonistic to FOL. Sugars can be added into the growth medium as carbon source to improve the growth and antagonistic ability of the yeast. This research was objected to determine the appropriate concentration of several sugars as carbon sources that could improve the growth and the antagonism of C. tropicalis against FOL. The experiment was arranged in a Completely Randomized Design consisted of 16 treatments and 3 replicates. The treatments were kinds of sugar, i.e. glucose, sucrose, trehalose, D-xylose, and Dmannitol, each at the concentration of $1 \%, 2.5 \%$, and $5 \%$, and two controls (half dextrose PDA and full dextrose PDA). The results showed that D-mannitol $1 \%$ was able to produce the longest colony length of $C$. tropicalis $(4.80 \mathrm{~cm})$ compared to control $(4.07 \mathrm{~cm})$. The widest colony $(1.47$ $\mathrm{cm})$, was produced by the treatment of $2.5 \%$ sucrose, compared to control $(1.00 \mathrm{~cm})$. All of the sugar addition treatments at different concentrations increased the cell densities of C. tropicalis. The highest number was showed by the addition of $1 \%$ trehalose, which yielded up to $4.27 \times 10^{7}$ cells $/ \mathrm{ml}$, compared to $0.1 \times 10^{7}$ cells $/ \mathrm{ml}$ at control. Addition of $2.5 \%$ trehalosa improved the antagonism of yeast with the highest inhibition of $23.68 \%$ compared to control with full dextrose PDA.

Keywords: Antagonistic agents, D-mannitol, Fusarium oxysporum f.sp. lycopersici, Trehalose

\begin{abstract}
ABSTRAK
Layu fusarium merupakan salah satu penyakit utama pada tanaman tomat yang disebabkan oleh Fusarium oxysporum f.sp. lycopersici (FOL) Salah satu agens antagonis yang dapat menghambat pertumbuhan FOL adalah khamir Candida tropicalis. Pertumbuhan dan kemampuan antagonisme khamir dapat ditingkatkan dengan penambahan gula sebagai sumber nutrisi. Penelitian ini bertujuan untuk mendapatkan konsentrasi dan jenis gula yang dapat meningkatkan pertumbuhan dan antagonisme $C$. tropicalis terhadap FOL. Percobaan dilakukan dengan menggunakan Rancangan Acak Lengkap yang terdiri atas 16 perlakuan dan 3 ulangan. Perlakuan terdiri atas jenis gula yang ditambahkan pada medium tumbuh khamir yaitu glukosa, sukrosa, trehalosa, D-xylose, dan D-mannitol dengan konsentrasi masing-masing gula 1\%, 2,5\%, 5\%, dan kontrol (PDA setengah dekstros dan PDA dekstros penuh). Hasil percobaan menunjukkan bahwa D-mannitol 1\% mampu meningkatkan panjang koloni $C$. tropicalis tertinggi sebesar $4,80 \mathrm{~cm}$, dibanding kontrol $(4,07 \mathrm{~cm})$. Sukrosa $2,5 \%$ mampu meningkatkan lebar koloni tertinggi sebesar $1,47 \mathrm{~cm}$, dibanding kontrol $(1,00 \mathrm{~cm})$. Seluruh perlakuan mampu meningkatkan kerapatan sel khamir C. tropicalis. Kerapatan sel tertinggi dihasilkan oleh trehalosa $1 \%$ sebesar $4,27 \times 10^{7}$, sementara pada kontrol 0,1
\end{abstract}


x $10^{7} \mathrm{sel} / \mathrm{ml}$. Gula trehalosa 2,5\% dapat meningkatkan antagonisme khamir dengan daya hambat tertinggi sebesar 23,68\%, dibandingkan dengan kontrol PDA dekstros penuh.

Kata Kunci: Agens antagonis, D-mannitol, Fusarium oxysporum f.sp. lycopersici, Trehalose

\section{PENDAHULUAN}

Tomat (Lycopersicon esculentum) adalah salah satu komoditas sayuran penting di Indonesia. Tingginya kandungan nutrisi dan banyaknya manfaat tomat menyebabkan tomat dibutuhkan hampir setiap hari. Meskipun produktivitas tomat di Indonesia selama periode 2017 ke 2018 mengalami peningkatan, akan tetapi produktivitas tomat tersebut masih di bawah potensi produksi yang seharusnya. Produktivitas tomat pada tahun 2017 sebesar 17,31 ton/ha, sedangkan pada tahun 2018 mencapai 18,41 ton/ha (Direktorat Jendral Hortikultura, 2018). Potensi produksi tomat seharusnya dapat mencapai 45,34 $-73,58$ ton/ha (Syukur, 2015). Rendahnya produktivitas tomat di Indonesia salah satunya disebabkan oleh adanya serangan Fusarium oxysporum f.sp. lycopersici (FOL), penyebab penyakit layu (Nurhayati, 2010). Penyakit layu fusarium mengakibatkan kerugian 20 hingga 30\% (Susanna dkk., 2010).

Salah satu pengendalian penyakit layu pada tomat yang ramah lingkungan adalah dengan memanfaatkan mikrob antagonis. Khamir merupakan salah satu mikrob yang berpotensi sebagai agens antagonis. Khamir genus Candida memiliki potensi untuk mengendalikan beberapa patogen tanaman (Chanchaichaovivat et al., 2007; Wilia et al., 2012, Sriram \& Poornachanddra, 2013). Salah satu khamir genus Candida yang telah diketahui berpotensi sebagai agens antagonis adalah C. tropicalis. Spesies khamir ini telah dilaporkan mampu mengendalikan penyakit antraknosa yang disebabkan oleh Colletotricum acutatum pada cabai (Hartati, 2016).

Mekanisme antagonisme khamir dapat berupa kompetisi ruang dan nutrisi (Sharma et al., 2009). Salah satu nutrisi yang dibutuhkan oleh khamir adalah gula. Gula dibutuhkan oleh khamir baik dalam proses oksidasi, asimilasi, maupun fermentasi. Gula sebagai sumber karbon dibutuhkan dalam pertumbuhan optimal khamir yang akan menentukan karakter fenotipik dan morfologi (Barnett et al., 2000). Penambahan beberapa gula telah dilaporkan dapat meningkatkan pertumbuhan dan kemampuan antagonisme khamir (Janisiewicz, 1994; Druvefors, 2004; Leepel et al., 2009;
Rahmawati, 2017; Hartati dkk. 2018). Beberapa gula seperti glukosa, manitol, dan maltose mampu meningkatkan pertumbuhan dan kemampuan antagonisme khamir. Penambahan gula pada media tumbuh khamir Pichia anomala mampu meningkatkan pertumbuhan dan antagonisme khamir tersebut (Druvefors, 2004), gula glukosa mampu meningkatkan pertumbuhan khamir $C$. albicans (Leepel et al., 2009), penambahan gula trehalosa mampu meningkatkan pertumbuhan dan antagonisme khamir Rhodotorula minuta (Hartati dkk., 2018). Peningkatan pertumbuhan dan kemampuan antagonisme khamir akibat penambahan gula juga sangat dipengaruhi oleh konsentrasi gula yang digunakan (Leepel et al., 2009).

Khamir C. tropicalis telah dilaporkan mampu memanfaatkan beberapa gula untuk pertumbuhannya. Gula yang dapat dimanfaatkan oleh C. tropicalis tersebut diantaranya adalah glukosa, sukrosa, trehalosa, D-xylose, dan Dmannitol (Hartati, 2017). Pengaruh gula tersebut terhadap peningkatan pertumbuhan dan kemampuan antagonisme khamir C. tropicalis belum diketahui. Penelitian ini bertujuan untuk mendapatkan konsentrasi dan jenis gula yang dapat meningkatkan pertumbuhan dan antagonisme $C$. tropicalis terhadap FOL.

\section{BAHAN DAN METODE}

Penelitian dilaksanakan di Laboratorium Bioteknologi Proteksi Tanaman, Departemen Hama dan Penyakit Tumbuhan, Fakultas Pertanian, Universitas Padjadjaran. Rancangan penelitian yang digunakan adalah Rancangan Acak Lengkap (RAL) dengan 16 perlakuan dan 3 ulangan. Perlakuan yang diuji adalah:

A. Penambahan gula glukosa $1 \%$

B. Penambahan gula glukosa $2,5 \%$

C. Penambahan gula glukosa $5 \%$

D. Penambahan gula sukrosa $1 \%$

E. Penambahan gula sukrosa $2,5 \%$

F. Penambahan gula sukrosa 5\%

G. Penambahan gula trehalosa $1 \%$

H. Penambahan gula trehalosa $2,5 \%$

I. Penambahan gula trehalose $5 \%$ 
J. Penambahan gula D-xylosa $1 \%$

K. Penambahan gula D- xylosa 2,5\%

L. Penambahan gula D- xylosa $5 \%$

M. Penambahan gula D-manitol $1 \%$

N. Penambahan gula D- manitol 2,5\%

O. Penambahan gula D- manitol 5\%

P. Kontrol tanpa penambahan gula pada PDA setengah dekstros

Q. Kontrol tanpa penambahan gula pada PDA dengan dekstros penuh

\section{Penyediaan C. tropicalis dan jamur FOL}

Khamir C. tropicalis yang digunakan dalam penelitian ini berasal dari hasil penelitian sebelumnya yang diisolasi dari buah cabai dari pertanaman cabai di Lumajang, Jawa Timur. Jamur FOL diisolasi dari batang tanaman tomat yang menunjukkan gejala penyakit layu fusarium. Khamir C. tropicalis diremajakan pada media Yeast Malt Extract broth (YMB), selanjutnya ditumbuhkan pada media Potato Dextrose Agar (PDA). Media PDA juga digunakan untuk perbanyakan jamur FOL. Perlakuan kemampuan tumbuh dan antagonisme khamir menggunakan media PDA setengah dekstros (10 g dekstros), sedangkan untuk kontrol menggunakan media PDA setengah dekstros (10 g dekstros) dan PDA dengan dekstros penuh (20 g dekstros).

\section{Uji Pengaruh Penambahan Gula terhadap Pertumbuhan Koloni Khamir C. tropicalis}

Pengujian dilakukan dengan menambahkan gula, yaitu glukosa, sukrosa, trehalosa, D-xylosa, dan D-manitol sesuai konsentrasi pada media PDA setengah dekstros. Khamir umur 5 hari ditumbuhkan dengan cara digores secara tegak lurus sebanyak 1 lup sepanjang $3 \mathrm{~cm}$ pada media PDA setengah dekstros yang telah diberi perlakuan gula dengan konsentrasi $1 \%$, 2,5\%, dan $5 \%$. Sebagai kontrol, khamir ditumbuhkan pada media PDA setengah dekstros dan PDA dengan dekstros penuh tanpa penambahan gula.

\section{Uji Pengaruh Penambahan Gula terhadap Kerapatan Sel Khamir}

Khamir C. tropicalis ditumbuhkan pada 100 $\mathrm{ml}$ akuades steril yang telah diberi perlakuan gula dan tanpa gula (kontrol). Khamir C. tropicalis umur 5 hari ditumbuhkan pada akuades tersebut sebanyak 1 lup, selanjutnya dishaker selama 24, 48, dan 72 jam (Hartati dkk., 2018). Kerapatan sel khamir dihitung dengan menggunakan haemasitometer.

\section{Pengaruh Penambahan Gula terhadap Peningkatan Kemampuan Antagonisme Khamir C. tropicalis}

Pengujian pengaruh penambahan gula terhadap peningkatan antagonisme $C$. tropicalis dilakukan secara in-vitro dengan metode dual culture. Khamir C. tropicalis dan FOL ditumbuhkan pada media PDA setengah dekstros yang telah ditambahkan gula sesuai perlakuan. Satu lup khamir berumur 5 hari digoreskan secara tegak lurus pada media tersebut, selanjutnya FOL umur 7 hari (diameter $6 \mathrm{~mm}$ ) ditumbuhkan di sebelah khamir dengan jarak $3 \mathrm{~cm}$. Sebagai kontrol, C. tropicalis dan FOL ditumbuhkan pada media PDA setengah dekstros dan PDA dengan dekstros penuh tanpa penambahan gula.

\section{Pengamatan Peningkatan Pertumbuhan Koloni Khamir}

Peningkatan pertumbuhan koloni khamir dengan penambahan gula diamati setiap hari sampai hari ke 12 setelah perlakuan. Peningkatan pertumbuhan khamir diketahui dengan mengukur panjang dan lebar koloni khamir (Gambar 1) baik pada perlakuaan maupun kontrol.

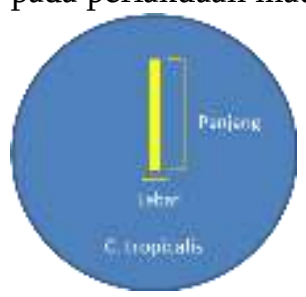

Gambar 1. Pengamatan peningkatan pertumbuhan khamir

\section{Pengamatan Kerapatan Sel Khamir}

Kerapatan sel khamir dihitung dari sel khamir yang tumbuh dalam akuades yang telah ditambah gula. Penghitungan kerapatan sel khamir dilakukan dengan menggunakan haemasitometer dan waktu pengamatan dilakukan dari 24, 48, dan 72 jam setelah perlakuan penambahan gula. Khamir $C$. tropicalis yang telah diinkubasi selama 24,48 , dan 72 jsp diambil sebanyak $1 \mathrm{ml}$ dan ditambahkan pada tabung rekasi yang telah berisi $9 \mathrm{ml}$ akuades. Kerapatan sel dihitung pada pengenceran $10^{-1}$ dengan metode hitung langsung menggunakan hemasitometer. Kerapatan sel dinyatakan dalam satuan $\mathrm{sel} / \mathrm{ml}$.

Pengamatan Peningkatan Kemampuan Antagonisme Khamir

Kemampuan antagonisme khamir $C$. tropicalis diketahui dengan mengukur diameter 
koloni FOL. Pengamatan dilakukan setiap hari sampai pertumbuhan FOL pada kontrol memenuhi cawan petri. Persentase hambatan dihitung dengan rumus:

Keterangan:

$$
\mathrm{DH}=\frac{\mathrm{Dk}-\mathrm{Dp}}{\mathrm{Dk}} \times 100 \%
$$

DH = Daya Hambat (\%)

Dk = Diameter FOL pada kontrol $(\mathrm{cm})$

$\mathrm{Dp}=$ Diameter FOL pada perlakuan $(\mathrm{cm})$

\section{Analisis Data}

Data yang diperoleh dianalisis dengan Analysis of Variance (ANOVA) untuk data yang menyebar normal dan analisis Kruskall Wallis untuk data yang tidak menyebar normal. Jika terdapat pengaruh perlakuan, maka dilakukan uji lanjut dengan uji Scott Knott dan Duncan untuk data menyebar normal dan uji Dunn untuk data tidak menyebar normal masing-masing pada taraf nyata
5\%. Data dianalisis menggunakan program SPSS Versi 26.0 for windows dan software R.

\section{HASIL DAN PEMBAHASAN}

\section{Pengaruh Penambahan Gula terhadap Pertumbuhan Koloni Khamir C. tropicalis}

Hasil pengamatan menunjukkan bahwa penambahan beberapa jenis gula berpengaruh terhadap pertumbuhan panjang koloni khamir $C$. tropicalis. Hasil tersebut terlihat pada pengamatan hari ke-11 dan ke-12. Pada hari ke-11 dan 12, koloni khamir C. tropicalis memperlihatkan pertumbuhan panjang yang maksimal. Sebelum hari ke-11 dan setelah hari ke-12, perlakuan penambahan gula tidak berpengaruh terhadap panjang koloni khamir $C$. tropicalis. Kisaran pertumbuhan panjang koloni khamir pada perlakuan penambahan gula di hari ke 11 sebesar 4,27 - 4,73 cm dan pada hari ke 12 sebesar 4,30 - 4,77 cm (Tabel 1).

Tabel 1. Pertumbuhan panjang koloni C. tropicalis pada perlakuan penambahan gula

\begin{tabular}{lcc}
\hline & \multicolumn{2}{c}{ Rata-rata panjang C.tropicalis \pm SD (cm) pada: } \\
\cline { 2 - 3 } Perlakuan & Hari ke-11 & Hari ke-12 \\
\hline A. Glukosa 1\% & $4,30 \pm 0,00 \mathrm{~b}$ & $4,40 \pm 0,00 \mathrm{~b}$ \\
B. Glukosa 2,5\% & $4,57 \pm 0,15 \mathrm{a}$ & $4,63 \pm 0,15 \mathrm{a}$ \\
C. Glukosa 5\% & $4,40 \pm 0,10 \mathrm{~b}$ & $4,47 \pm 0,06 \mathrm{~b}$ \\
D. Sukrosa 1\% & $4,40 \pm 0,35 \mathrm{~b}$ & $4,50 \pm 0,36 \mathrm{~b}$ \\
E. Sukrosa 2,5 \% & $4,70 \pm 0,10 \mathrm{a}$ & $4,73 \pm 0,15 \mathrm{a}$ \\
F. Sukrosa 5\% & $4,27 \pm 0,21 \mathrm{~b}$ & $4,37 \pm 0,21 \mathrm{~b}$ \\
G.Trehalosa 1\% & $4,40 \pm 0,17 \mathrm{~b}$ & $4,40 \pm 0,17 \mathrm{~b}$ \\
H.Trehalosa 2,5\% & $4,67 \pm 0,06 \mathrm{a}$ & $4,67 \pm 0,06 \mathrm{a}$ \\
I. Trehalosa 5\% & $4,73 \pm 0,40 \mathrm{a}$ & $4,77 \pm 0,46 \mathrm{a}$ \\
J. D-Xylose 1\% & $4,30 \pm 0,10 \mathrm{~b}$ & $4,30 \pm 0,10 \mathrm{~b}$ \\
K.D-Xylose 2,5\% & $4,30 \pm 0,26 \mathrm{~b}$ & $4,37 \pm 0,31 \mathrm{~b}$ \\
L.D-Xylose 5\% & $4,27 \pm 0,12 \mathrm{~b}$ & $4,30 \pm 0,10 \mathrm{~b}$ \\
M.D-Mannitol 1\% & $4,73 \pm 0,23 \mathrm{a}$ & $4,80 \pm 0,26 \mathrm{a}$ \\
N.D-Mannitol 2,5\% & $4,60 \pm 0,20 \mathrm{a}$ & $4,67 \pm 0,15 \mathrm{a}$ \\
O.D-Mannitol 5\% & $4,63 \pm 0,21 \mathrm{a}$ & $4,70 \pm 0,17 \mathrm{a}$ \\
P. Kontrol PDA 1/2 dekstros & $4,03 \pm 0,06 \mathrm{~b}$ & $4,07 \pm 0,06 \mathrm{~b}$ \\
Q. Kontrol PDA dekstros penuh & $4,30 \pm 0,17 \mathrm{~b}$ & $4,33 \pm 0,23 \mathrm{~b}$ \\
\hline
\end{tabular}

Keterangan: Angka rata-rata yang diikuti oleh huruf yang berbeda menunjukkan berbeda nyata berdasarkan uji Scott Knott pada taraf nyata $5 \%$.

Berdasarkan analisis statistik diketahui bahwa perlakuan penambahan glukosa 2,5\%, sukrosa $2,5 \%$, trehalose $2,5 \%$, trehalose $5 \%$, Dmannitol 1\%, D-mannitol 2,5\%, dan D-mannitol 5\% menunjukkan hasil yang berbeda nyata dengan perlakuan kontrol PDA setengah dekstros dan kontrol PDA dengan dekstros penuh pada hari ke-11 dan ke-12 (Tabel 1). Koloni C. Tropicalis terpanjang diperoleh pada hari ke-11 diperlihatkan oleh perlakuan penambahan gula trehalosa $5 \%$ dan Dmannitol 1\%, sedangkan koloni terpendek terjadi pada perlakuan gula D-xylosa 5\% (Gambar 2). Pada 
hari ke-12, koloni $C$. tropicalis terpanjang terjadi pada perlakuan penambahan gula D-mannitol $1 \%$, sedangkan koloni terpendek terjadi pada perlakuan gula D-xylosa 1\% dan D-xylosa 5\% (Gambar 3).
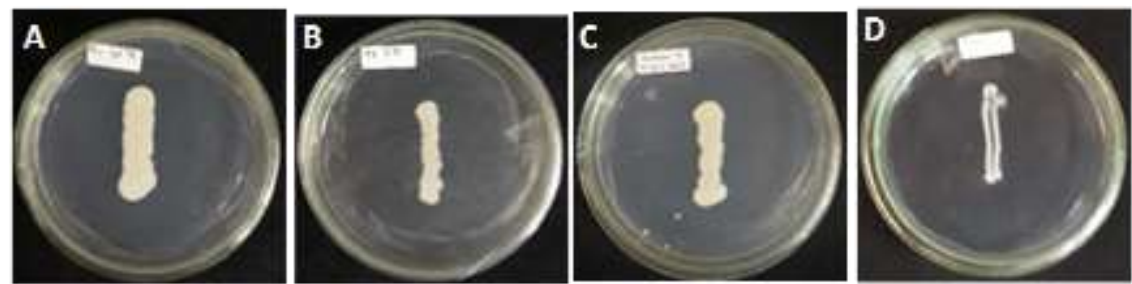

Gambar 2. Hasil uji pengaruh penambahan gula terhadap pertumbuhan panjang koloni khamir C. tropicalis pada hari ke-11 (A) trehalosa 5\%, (B) D-xylose 5\%, (C) Kontrol PDA dekstros penuh, (D) Kontrol PDA setengah dekstros.
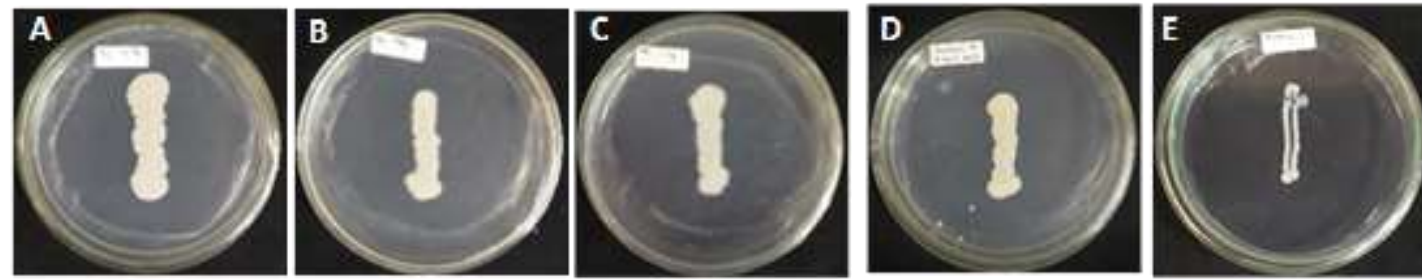

Gambar 3. Hasil uji pengaruh penambahan gula terhadap pertumbuhan panjang koloni khamir C. tropicalis pada hari ke-12 (A) D-mannitol 1\%, (B) D-xylose 1\%, (C) trehalosa 5\%, (D) Kontrol PDA dekstros penuh, (E) Kontrol PDA setengah dekstros.

Hasil pengamatan lebar koloni menunjukkan bahwa pada pengamatan sebelum dan sesudah hari ke-12 perlakuan gula tidak berpengaruh terhadap lebar koloni C. tropicalis. Hasil pengamatan pertumbuhan lebar koloni khamir C. tropicalis menunjukkan bahwa perlakuan beberapa gula berpengaruh terhadap lebar koloni khamir hanya pada hari ke-12. Berbeda dengan pengamatan panjang koloni, hasil pengamatan lebar khamir C.tropicalis pada hari ke-11 menunjukkan bahwa perlakuan penambahan gula tidak berpengaruh terhadap lebar khamir. Kisaran lebar koloni khamir C. tropicalis pada hari ke-11 yaitu 0,97-1,43 cm dan pada hari ke 12 yaitu 1,00-1,47 cm (Tabel 2).

Perlakuan glukosa 5\%, sukrosa 2,5\%, trehalosa 5\%, dan D-mannitol 1\% menghasilkan lebar koloni yang berbeda nyata dengan kontrol, baik kontrol PDA setengah dekstros maupun PDA dekstros penuh pada hari ke-12 (Tabel 2 dan Gambar 4). Beberapa perlakuan yang lain, seperti perlakuan trehalosa $1 \%$, D-xylose $1 \%$, D-xylose $2,5 \%$, D-xylose 5\%, dan D-mannitol 5\%, tidak berbeda nyata dengan kontrol PDA setengah dekstros dan PDA dekstros penuh dalam menghasikan lebar koloni C. tropicalis. Akan tetapi, hampir seluruh perlakuan penambahan gula menghasilkan koloni yang lebih lebar dibandingkan dengan kontrol PDA setengah dekstros (Tabel 2).

Secara umum, sumber karbon seperti gula diperlukan untuk pertumbuhan dan perkembangan mikrob. Gula dan sumber nutrisi lainnya dalam media tumbuh dimanfaatkan oleh khamir dengan cara didegradasi selanjutnya digunakan untuk melakukan metabolisme. Nutrisi akan diubah menjadi energi dan materi sel baru bagi khamir pada proses metabolism tersebut. Hasil proses tersebut akan menyebabkan khamir mampu tumbuh pada media (Kamel, 2016). Berdasarkan penelitian sebelumnya diketahui bahwa khamir C. tropicalis dapat memanfaatkan beberapa gula untuk pertumbuhannya, seperti glukosa, sukrosa, trehalosa, mannitol, dan D-xylose (Hartati dkk., 2017). Hasil penelitian ini menunjukkan bahwa empat jenis gula yang dapat dimanfaatkan oleh khamir C. tropicalis yaitu sukrosa, trehalosa, dan mannitol mampu meningkatkan pertumbuhan panjang dan lebar koloni khamir tersebut. Secara umum, sumber karbon seperti gula diperlukan untuk pertumbuhan dan perkembangan mikrob. Gula dan sumber nutrisi lainnya dalam media tumbuh dimanfaatkan oleh khamir dengan cara didegradasi selanjutnya digunakan untuk melakukan metabolisme. Nutrisi akan diubah menjadi energi dan materi sel baru bagi khamir pada proses metabolism tersebut. 
Hasil proses tersebut akan menyebabkan khamir mampu tumbuh pada media (Kamel, 2016). Berdasarkan penelitian sebelumnya diketahui bahwa khamir C. tropicalis dapat memanfaatkan beberapa gula untuk pertumbuhannya, seperti glukosa, sukrosa, trehalosa, mannitol, dan D-xylose (Hartati dkk., 2017). Hasil penelitian ini menunjukkan bahwa empat jenis gula yang dapat dimanfaatkan oleh khamir C. tropicalis yaitu sukrosa, trehalosa, dan mannitol mampu meningkatkan pertumbuhan panjang dan lebar koloni khamir tersebut.

Tabel 2. Pertumbuhan lebar koloni C. tropicalis pada perlakuan penambahan gula

\begin{tabular}{lcc}
\hline \multicolumn{1}{c}{ Perlakuan } & \multicolumn{2}{c}{ Rata-rata lebar C.tropicalis \pm SD $(\mathrm{cm})$ pada } \\
& Hari ke-11 & Hari ke-12 \\
\hline A. Glukosa 1\% & $1,20 \pm 0,10 \mathrm{a}$ & $1,20 \pm 0,00 \mathrm{bcde}$ \\
B. Glukosa 2,5\% & $1,20 \pm 0,10 \mathrm{a}$ & $1,20 \pm 0,10 \mathrm{bcde}$ \\
C. Glukosa 5\% & $1,23 \pm 0,06 \mathrm{a}$ & $1,23 \pm 0,06 \mathrm{cde}$ \\
D. Sukrosa 1\% & $1,23 \pm 0,25 \mathrm{a}$ & $1,30 \pm 0,26 \mathrm{bcde}$ \\
E. Sukrosa 2,5 \% & $1,43 \pm 0,15 \mathrm{a}$ & $1,47 \pm 0,12 \mathrm{e}$ \\
F. Sukrosa 5\% & $1,13 \pm 0,06 \mathrm{a}$ & $1,23 \pm 0,15 \mathrm{bcde}$ \\
G.Trehalosa 1\% & $1,07 \pm 0,15 \mathrm{a}$ & $1,07 \pm 0,15 \mathrm{abc}$ \\
H.Trehalosa 2,5\% & $1,17 \pm 0,06 \mathrm{a}$ & $1,17 \pm 0,06 \mathrm{bcde}$ \\
I. Trehalosa 5\% & $1,30 \pm 0,30 \mathrm{a}$ & $1,33 \pm 0,25 \mathrm{cde}$ \\
J. D-Xylose 1\% & $1,10 \pm 0,10 \mathrm{a}$ & $1,10 \pm 0,10 \mathrm{abcd}$ \\
K.D-Xylose 2,5\% & $1,10 \pm 0,10 \mathrm{a}$ & $1,10 \pm 0,10 \mathrm{abc}$ \\
L.D-Xylose 5\% & $1,13 \pm 0,06 \mathrm{a}$ & $1,13 \pm 0,06 \mathrm{abcd}$ \\
M.D-Mannitol 1\% & $1,40 \pm 0,17 \mathrm{a}$ & $1,40 \pm 0,17 \mathrm{de}$ \\
N.D-Mannitol 2,5\% & $1,13 \pm 0,12 \mathrm{a}$ & $1,13 \pm 0,12 \mathrm{bcde}$ \\
O.D-Mannitol 5\% & $1,07 \pm 0,15 \mathrm{a}$ & $1,07 \pm 0,15 \mathrm{abc}$ \\
P.Kontrol PDA $1 / 2$ dekstros & $0,97 \pm 0,06 \mathrm{a}$ & $1,00 \pm 0,00 \mathrm{a}$ \\
Q.Kontrol PDA dekstros penuh & $0,97 \pm 0,06 \mathrm{a}$ & $1,00 \pm 0,00 \mathrm{ab}$ \\
\hline
\end{tabular}

Keterangan: Angka rata-rata yang diikuti oleh huruf yang berbeda menunjukkan perbedaan nyata berdasarkan uji Dunn pada taraf nyata $5 \%$.

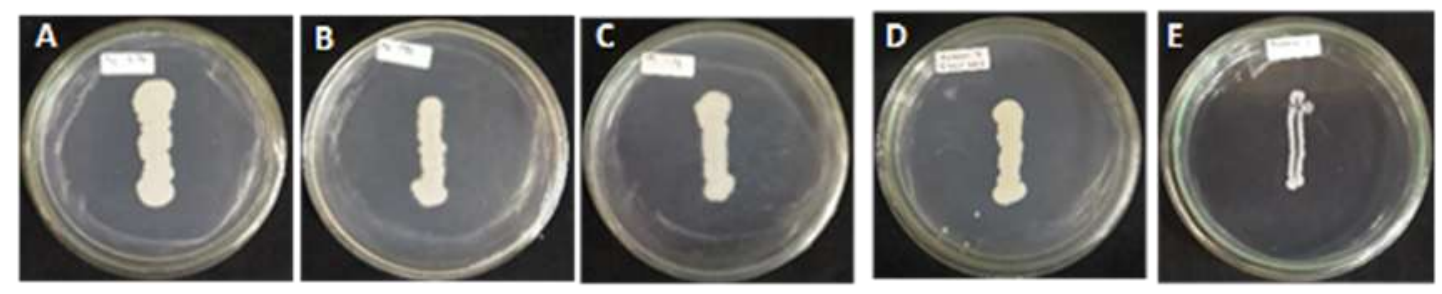

Gambar 4. Hasil uji pengaruh penambahan gula terhadap pertumbuhan lebar koloni khamir C. tropicalis pada hari ke-12 (A) sukrosa 2,5\%, (B) sukrosa 1\%, (C) D-mannitol 1\%, (D) trehalosa 5\% (E) kontrol PDA setengah dekstros.

Meningkatnya pertumbuhan khamir $C$. perubahan fisika maupun kimia pada lingkungan tropicalis dengan perlakuan penambahan beberapa jenis gula dapat dipengaruhi oleh sifat gula dan konsentrasinya. Menurut Leepel et al. (2009) gula glukosa dapat menyebabkan kondisi isotonis pada medium pertumbuhan khamir sehingga terjadi keseimbangan cairan makanan yang akhirnya dapat meningkatkan pertumbuhan khamir. Gula sukrosa mampu memaksimalkan proses fermentasi yang baik bagi khamir (Türker, 2014). Gula trehalosa merupakan gula yang tidak mudah mengalami medianya sehingga dapat dimanfaatkan untuk pertumbuhan khamir (Sedijani, 2014). Gula trehalosa juga memiliki sifat sebagai penstabil materi biologi atau biological stabilizing agent (Shinohara et al., 2002). Gula mannitol merupakan gula alkohol, dan gula mannitol dapat memengaruhi pertumbuhan khamir. Selain jenis dan sifat gula, konsentrasi gula dalam media juga dapat memengaruhi pertumbuhan khamir. Menurut Leepel et al. (2009) konsentrasi gula yang digunakan 
dalam penambahan gula dapat memengaruhi peningkatan pertumbuhan dan kemampuan antagonisme khamir.

\section{Pengaruh Penambahan Gula terhadap Kerapatan Sel} Khamir

Berdasarkan hasil pengamatan terhadap kerapatan sel menunjukkan bahwa penambahan gula berpengaruh terhadap kerapatan sel khamir $C$. tropicalis. Hal tersebut ditunjukkan dengan adanya peningkatan kerapatan sel khamir $C$. tropicalis pada perlakuan penambahan gula glukosa, sukrosa, trehalosa, D-xylose, dan D-mannitol dengan kosentrasi 1\%, 2,5\%, dan 5\% (Tabel 3).

Tabel 3. Kerapatan sel khamir C. tropicalis dengan penambahan gula

\begin{tabular}{llll}
\hline \multirow{2}{*}{ Perlakuan } & \multicolumn{2}{c}{ Rata-rata kerapatan sel C. tropicalis \pm SD (sel/ml) pada pengamatan } \\
\cline { 2 - 4 } & \multicolumn{1}{c}{ Jam ke-24 } & \multicolumn{1}{c}{ Jam ke-48 } & \multicolumn{1}{c}{ Jam ke- 72} \\
\hline A. Glukosa $1 \%$ & $1,43 \pm 1,08 \times 10^{7} \mathrm{ab}$ & $2,87 \pm 0,23 \times 10^{7} \mathrm{ab}$ & $2,93 \pm 0,4 \times 10^{7} \mathrm{~cd}$ \\
B. Glukosa 2,5\% & $0,12 \pm 0,03 \times 10^{7} \mathrm{~b}$ & $2,23 \pm 0,21 \times 10^{7} \mathrm{ab}$ & $2,3 \pm 0,26 \times 10^{7} \mathrm{e}$ \\
C. Glukosa 5\% & $0,17 \pm 0,06 \times 10^{7} \mathrm{ab}$ & $2,33 \pm 0,21 \times 10^{7} \mathrm{ab}$ & $3,07 \pm 0,06 \times 10^{7} \mathrm{~cd}$ \\
D. Sukrosa 1\% & $0,19 \pm 0,01 \times 10^{7} \mathrm{ab}$ & $3 \pm 0,17 \times 10^{7} \mathrm{ab}$ & $4,17 \pm 0,32 \times 10^{7} \mathrm{a}$ \\
E. Sukrosa 2,5\% & $0,81 \pm 1,12 \times 10^{7} \mathrm{ab}$ & $3 \pm 0,56 \times 10^{7} \mathrm{ab}$ & $3,83 \pm 0,5 \times 10^{7} \mathrm{ab}$ \\
F. Sukrosa 5\% & $2 \pm 1,57 \times 10^{7} \mathrm{ab}$ & $3,63 \pm 0,47 \times 10^{7} \mathrm{ab}$ & $4,07 \pm 0,49 \times 10^{7} \mathrm{a}$ \\
G.Trehalosa 1\% & $0,75 \pm 0,13 \times 10^{7} \mathrm{ab}$ & $1,13 \pm 0 \times 10^{7} \mathrm{~b}$ & $4,27 \pm 0,29 \times 10^{7} \mathrm{a}$ \\
H.Trehalosa 2,5\% & $0,71 \pm 0,71 \times 10^{7} \mathrm{ab}$ & $2,4 \pm 0,1 \times 10^{7} \mathrm{ab}$ & $3,33 \pm 0,21 \times 10^{7} \mathrm{bc}$ \\
I. Trehalosa 5\% & $6,03 \pm 0,6 \times 10^{7} \mathrm{ab}$ & $3,73 \pm 0,59 \times 10^{7} \mathrm{ab}$ & $3,3 \pm 0,26 \times 10^{7} \mathrm{bc}$ \\
J. D-Xylose 1\% & $1,13 \pm 1,07 \times 10^{7} \mathrm{ab}$ & $3,17 \pm 0,21 \times 10^{7} \mathrm{ab}$ & $3,4 \pm 0,1 \times 10^{7} \mathrm{bc}$ \\
K. D-Xylose 2,5\% & $4,17 \pm 0,12 \times 10^{7} \mathrm{ab}$ & $2,87 \pm 0,06 \times 10^{7} \mathrm{ab}$ & $3,1 \pm 0,2 \times 10^{7} \mathrm{~cd}$ \\
L. D-Xylose 5\% & $4,27 \pm 0,23 \times 10^{7} \mathrm{ab}$ & $3,27 \pm 0,15 \times 10^{7} \mathrm{abb}$ & $3,37 \pm 0,06 \times 10^{7} \mathrm{bc}$ \\
M. D-Mannitol 1\% & $11,33 \pm 0,84 \times 10^{7} \mathrm{a}$ & $6,3 \pm 0,62 \times 10^{7} \mathrm{a}$ & $3,43 \pm 0,06 \times 10^{7} \mathrm{bc}$ \\
N. D-Mannitol 2,5\% & $5,2 \pm 0,17 \times 10^{7} \mathrm{ab}$ & $4,37 \pm 0,25 \times 10^{7} \mathrm{ab}$ & $2,2 \pm 0,17 \times 10^{7} \mathrm{e}$ \\
O. D-Mannitol 5\% & $4,97 \pm 0,06 \times 10^{7} \mathrm{ab}$ & $4,4 \pm 0,17 \times 10^{7} \mathrm{ab}$ & $2,67 \pm 0,67 \times 10^{7} \mathrm{de}$ \\
P. Kontrol & $7,1 \pm 0,72 \times 10^{7} \mathrm{ab}$ & $1,5 \pm 1,4 \times 10^{7} \mathrm{ab}$ & $0,1 \pm 0 \times 10^{7} \mathrm{f}$ \\
\hline
\end{tabular}

Keterangan: Angka rata-rata yang diikuti oleh huruf yang berbeda menunjukkan perbedaan nyata berdasarkan uji Duncan pada taraf nyata $5 \%$.

Berdasarkan hasil pengamatan pada 24 jam setelah perlakuan (jsp) diketahui bahwa perlakuan glukosa 2,5\% menghasilkan kerapatan khamir yang berbeda nyata dengan D-mannitol 1\%, yaitu kerapatan khamir pada glukosa 2,5\% lebih sedikit dibandingkan dengan kerapatan khamir pada Dmannitol 1\%. Akan tetapi, apabila dibandingkan dengan kontrol semua perlakuan tidak berbeda nyata dengan kontrol pada 24 jsp, meskipun terdapat peningkatan kerapatan sel di seluruh perlakuan. Kerapatan sel tertinggi terjadi pada perlakuan Dmannitol $1 \%$ dengan nilai kerapatan $11,33 \times 10^{7}$ $\mathrm{sel} / \mathrm{ml}$ dan kerapatan sel terendah terjadi pada perlakuan glukosa 2,5\% yaitu sebesar $0,12 \times 10^{7}$ (Tabel 3).

Pada pengamatan 48 jsp, terjadi peningkatan kerapatan sel khamir di hampir seluruh perlakuan penambahan gula. Akan tetapi, kerapatan sel tersebut menunjukkan nilai yang tidak berbeda nyata dengan kontrol, meskipun jumlah sel khamir pada kontrol lebih sedikit. Kerapatan sel khamir $C$. tropicalis pada perlakuan D-mannitol $1 \%$ memiliki tingkat kerapatan sel yang tinggi yaitu $6,3 \times 10^{7}$ sel/ml. Perlakuan penambahan trehalosa $1 \%$ menghasilkan kerapatan sel terendah yaitu $1,13 \mathrm{x}$ $10^{7}$ (Tabel 3). Pada pengamatan 72 jsp, kerapatan sel khamir C. tropicalis pada seluruh perlakuan penambahan gula menunjukkan berbeda nyata dengan kontrol. Kerapatan sel tertinggi terdapat pada perlakuan trehalosa $1 \%$ yaitu sebesar $4,27 \times 10^{7}$ dan kerapatan sel terendah terjadi pada perlakuan D-Mannitol 2,5\% yaitu sebesar 2,2 x 107.

Hasil pengamatan terhadap kerapatan sel menunjukkan bahwa sel khamir $C$. tropicalis pada beberapa perlakuan masih mengalami peningkatan kerapatan sel pada 72 jsp, sedangkan pada sebagian kecil perlakuan yang lain mengalami penurunan. Hal ini menunjukkan bahwa sel khamir masih 
mampu tumbuh hingga 72 jam. Peningkatan atau kematian sel khamir tergantung pada nutrisi, lingkungan dan mikrob (Váchová, 2012).

Sel khamir mengalami beberapa fase dalam pertumbuhannya. Fase pertumbuhan khamir diawali dengan fase lag, pada fase ini khamir akan menyerap nutrisi dari sumber karbon yang tersedia. Setelah fase lag, sel khamir akan masuk fase eksponensial yaitu fase ketika khamir mengalami peningkatan populasi selnya. Fase peningkatan sel khamir akan dilanjutkan dengan fase lisis yaitu merupakan fase sel khamir mengalami kematian dan akan mengeluarkan isi selnya yang dapat digunakan oleh sebagian sel khamir yang masih hidup sebagai sumber nutrisi (Fardiaz, 1992). Kejadian ini memungkinkan adanya pertumbuhan sel baru. Setelah fase eksponensial, sel khamir akan mengalami pertumbuhan yang lambat dan memasuki fase stasioner, pada fase ini terjadi penurunan kandungan nutrisi dan akumulasi limbah metabolism, serta sel khamir dari sebagian populasi mengalami kematian (Váchová, 2012).

Pengaruh Penambahan Gula dalam Meningkatkan Kemampuan Antagonisme khamir C. tropicalis terhadap FOL

Perlakuan penambahan gula pada media PDA berpengaruh terhadap kemampuan antagonisme khamir C. tropicalis. Kisaran diameter FOL pada hari ke-11 adalah 3,00-4,53 cm dan pada hari ke-12 adalah 3,03-4,47 cm (Tabel 4). Diameter FOL terkecil dihasilkan oleh perlakuan trehalosa 2,5\%. Akan tetapi, nilai diameter tersebut tidak berbeda nyata dengan kontrol $(3,47 \mathrm{~cm})$.

Pada pengamatan hari ke-11 dan ke-12, perlakuan penambahan gula trehalosa $1 \%$, trehalosa $5 \%$, D-xylose 2,5\%, xylose 5\%, D-mannitol 1\%, Dmannitol 2,5\% dan D-mannitol 5\% menunjukkan pertumbuhan FOL yang berbeda nyata dengan kontrol PDA setengah dekstros (Tabel 4). Perbedaan yang signifikan tersebut disebabkan oleh karena diameter FOL pada perlakuan lebih tinggi dibandingkan dengan kontrol PDA setengah dekstros (Gambar 5).

Sebagian besar perlakuan penambahan berbagai gula pada media PDA setengah dekstros tidak mampu meningkatkan daya hambat khamir $C$. tropicalis dalam menekan pertumbuhan FOL. Hal ini ditunjukan dengan nilai daya hambat yang negatif jika dibandingkan dengan kontrol setengah dekstros (Tabel 4). Hanya beberapa perlakuan penambahan gula yang memiliki nilai daya hambat positif yaitu perlakuan glukosa $5 \%$, sukrosa $5 \%$, trehalosa $1 \%$, trehalosa $2,5 \%$, dan $\mathrm{D}$-xylose $1 \%$ (Tabel 4).

Tabel 4. Kemampuan antagonisme khamir C. tropicalis terhadap FOL dengan perlakuan penambahan gula pada media kontrol PDA setengah dekstros

\begin{tabular}{lcccc}
\hline \multirow{2}{*}{\multicolumn{1}{c}{ Perlakuan }} & \multicolumn{2}{c}{ Diameter FOL $(\mathrm{cm})$} & \multicolumn{2}{c}{ Daya hambat $(\%)$} \\
\cline { 2 - 5 } A. Glukosa 1\% & Hari ke-11 & Hari ke-12 & Hari ke-11 & Hari ke-12 \\
B. Glukosa 2,5\% & $3,27 \pm 0,47 \mathrm{~b}$ & $3,73 \pm 0,23 \mathrm{~b}$ & $-6,51$ & $-7,50$ \\
C. Glukosa 5\% & $3,57 \pm 0,45 \mathrm{~b}$ & $3,70 \pm 0,50 \mathrm{~b}$ & $-16,29$ & $-6,60$ \\
D. Sukrosa 1\% & $3,33 \pm 0,55 \mathrm{~b}$ & $3,40 \pm 0,61 \mathrm{~b}$ & $-8,47$ & 2,00 \\
E. Sukrosa 2,5 \% & $3,23 \pm 0,06 \mathrm{~b}$ & $3,63 \pm 0,29 \mathrm{~b}$ & $-5,21$ & $-4,60$ \\
F. Sukrosa 5\% & $3,30 \pm 0,35 \mathrm{~b}$ & $3,77 \pm 0,31 \mathrm{~b}$ & $-7,49$ & $-8,60$ \\
G.Trehalosa 1\% & $3,17 \pm 0,50 \mathrm{~b}$ & $3,33 \pm 0,55 \mathrm{~b}$ & $-3,26$ & 4,00 \\
H.Trehalosa 2,5\% & $4,07 \pm 0,75 \mathrm{a}$ & $4,37 \pm 0,40 \mathrm{a}$ & $-32,57$ & $-25,94$ \\
I. Trehalosa 5\% & $3,00 \pm 0,00 \mathrm{~b}$ & $3,03 \pm 0,06 \mathrm{~b}$ & 2,28 & 12,70 \\
J. D-Xylose 1\% & $4,23 \pm 0,25 \mathrm{a}$ & $4,37 \pm 0,31 \mathrm{a}$ & $-37,79$ & $-25,94$ \\
K.D-Xylose 2,5\% & $3,33 \pm 0,67 \mathrm{~b}$ & $3,40 \pm 0,69 \mathrm{~b}$ & $-8,47$ & 2,00 \\
L.D-Xylose 5\% & $4,13 \pm 0,35 \mathrm{a}$ & $4,30 \pm 0,17 \mathrm{a}$ & $-34,53$ & $-23,90$ \\
M.D-Mannitol 1\% & $4,00 \pm 0,20 \mathrm{a}$ & $4,20 \pm 0,10 \mathrm{a}$ & $-30,29$ & $-21,00$ \\
N.D-Mannitol 2,5\% & $3,90 \pm 0,96 \mathrm{a}$ & $4,47 \pm 0,64 \mathrm{a}$ & $-27,04$ & $-28,80$ \\
O.D-Mannitol 5\% & $3,93 \pm 0,74 \mathrm{a}$ & $4,17 \pm 0,51 \mathrm{a}$ & $-28,01$ & $-20,20$ \\
P.Kontrol PDA setengah dekstros & $3,07 \pm 0,12 \mathrm{~b}$ & $3,47 \pm 0,35 \mathrm{~b}$ & $-47,56$ & $-34,60$ \\
\hline
\end{tabular}

Keterangan: Angka rata-rata yang diikuti oleh huruf yang berbeda menunjukkan perbedaan nyata berdasarkan uji Scott Knott pada taraf nyata $5 \%$. 


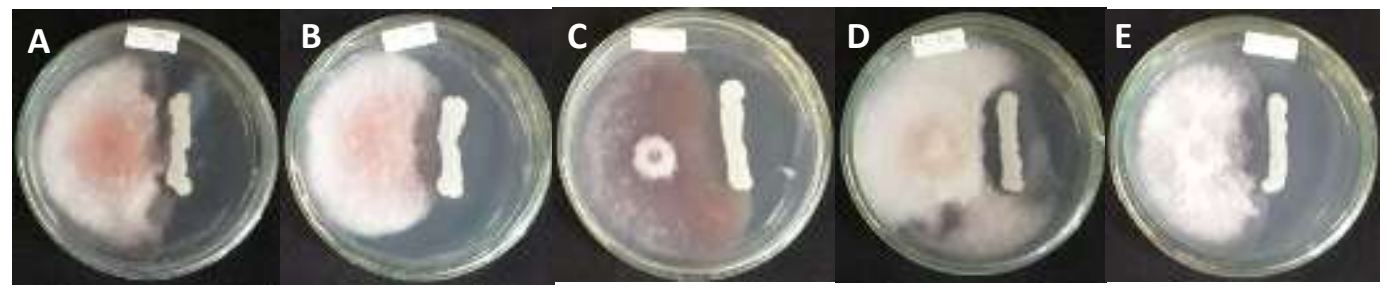

Gambar 5. Hasil uji pengaruh penambahan gula untuk meningkatkan kemampuan antagonisme khamir $C$. tropicalis pada hari ke-11 (A) trehalosa 1\% (B) trehalosa 5\% (C) D-xylose 1\%(D) D-mannitol $5 \%$ (E) Kontrol PDA setengah dekstros.

Apabila dibandingkan dengan kontrol PDA setengah dekstros, nilai daya hambat khamir $C$. tropicalis dengan menggunakan kontrol PDA dekstros penuh lebih tinggi (Tabel 5). Nilai daya hambat positif terdapat pada perlakuan glukosa $1 \%$, glukosa $2,5 \%$, glukosa $5 \%$, sukrosa $1 \%$, sukrosa
$2,5 \%$, sukrosa $5 \%$, trehalosa $2,5 \%$, dan D-xylose $1 \%$ (Tabel 5). Nilai daya hambat tertinggi pada kontrol PDA dengan dekstros penuh terjadi pada perlakuan trehalosa $2,5 \%$ yaitu sebesar $23,68 \%$ pada hari ke-12 (Tabel 5 dan Gambar 6).

Tabel 5. Kemampuan antagonisme khamir C. tropicalis terhadap FOL dengan perlakuan penambahan gula pada media kontrol PDA dekstros penuh

\begin{tabular}{lcccc}
\hline \multirow{2}{*}{ Perlakuan } & \multicolumn{2}{c}{ Diameter FOL $(\mathrm{cm})$} & \multicolumn{2}{c}{ Daya hambat $(\%)$} \\
\cline { 2 - 5 } & Hari ke-11 & Hari ke-12 & Hari ke-11 & Hari ke-12 \\
\hline A. Glukosa 1\% & $3,27 \pm 0,47 \mathrm{~b}$ & $3,73 \pm 0,23 \mathrm{~b}$ & 13,26 & 6,05 \\
B. Glukosa 2,5 \% & $3,57 \pm 0,45 \mathrm{~b}$ & $3,70 \pm 0,50 \mathrm{~b}$ & 5,31 & 6,80 \\
C. Glukosa 5\% & $3,33 \pm 0,55 \mathrm{~b}$ & $3,40 \pm 0,61 \mathrm{~b}$ & 11,67 & 14,36 \\
D. Sukrosa 1\% & $3,23 \pm 0,06 \mathrm{~b}$ & $3,63 \pm 0,29 \mathrm{~b}$ & 14,32 & 8,56 \\
E. Sukrosa 2,5 \% & $3,30 \pm 0,35 \mathrm{~b}$ & $3,77 \pm 0,31 \mathrm{~b}$ & 12,47 & 5,04 \\
F. Sukrosa 5\% & $3,17 \pm 0,50 \mathrm{~b}$ & $3,33 \pm 0,55 \mathrm{~b}$ & 15,92 & 16,12 \\
G.Trehalosa 1\% & $4,07 \pm 0,75 \mathrm{a}$ & $4,37 \pm 0,40 \mathrm{a}$ & $-7,96$ & $-10,08$ \\
H.Trehalosa 2,5\% & $3,00 \pm 0,00 \mathrm{~b}$ & $3,03 \pm 0,06 \mathrm{~b}$ & 20,42 & 23,68 \\
I. Trehalosa 5\% & $4,23 \pm 0,25 \mathrm{a}$ & $4,37 \pm 0,31 \mathrm{a}$ & $-12,20$ & $-10,08$ \\
J. D-Xylose 1\% & $3,33 \pm 0,67 \mathrm{~b}$ & $3,40 \pm 0,69 \mathrm{~b}$ & 11,70 & 14,40 \\
K.D-Xylose 2,5\% & $4,13 \pm 0,35 \mathrm{a}$ & $4,30 \pm 0,17 \mathrm{a}$ & $-9,50$ & $-8,30$ \\
L.D-Xylose 5\% & $4,00 \pm 0,20 \mathrm{a}$ & $4,20 \pm 0,10 \mathrm{a}$ & $-6,10$ & $-5,80$ \\
M.D-Mannitol 1\% & $3,90 \pm 0,96 \mathrm{a}$ & $4,47 \pm 0,64 \mathrm{a}$ & $-3,40$ & $-12,60$ \\
N.D-Mannitol 2,5\% & $3,93 \pm 0,74 \mathrm{a}$ & $4,17 \pm 0,51 \mathrm{a}$ & $-4,20$ & $-5,00$ \\
O.D-Mannitol 5\% & $4,53 \pm 0,29 \mathrm{a}$ & $4,67 \pm 0,42 \mathrm{a}$ & $-20,20$ & $-17,60$ \\
P.Kontrol PDA dekstros penuh & $3,77 \pm 0,21 \mathrm{a}$ & $3,97 \pm 0,25 \mathrm{a}$ & 0,00 & 0,00 \\
\hline
\end{tabular}

Keterangan: Angka rata-rata yang diikuti oleh huruf yang berbeda menunjukkan perbedaan nyata berdasarkan uji Scott Knott pada taraf nyata $5 \%$.

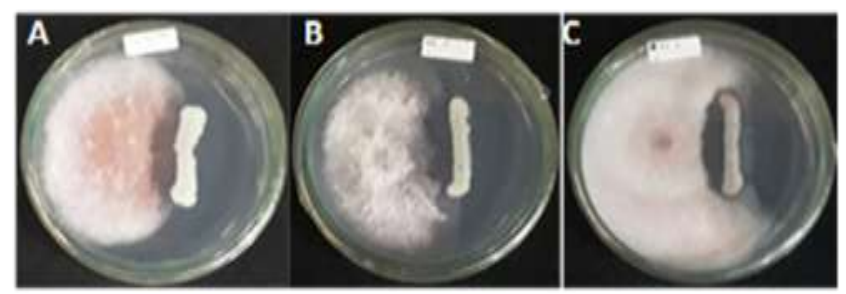

Gambar 6. Hasil uji pengaruh penambahan gula untuk meningkatkan kemampuan antagonisme khamir $C$. tropicalis pada hari ke-12 (A) trehalosa 2,5\% (B) kontrol PDA setengah dekstros (C) kontrol PDA dekstros penuh. 
Hasil penelitian ini menunjukkan bahwa konsentrasi dekstros yang rendah pada kontrol dengan media PDA setengah dekstros menyebabkan terhambatnya pertumbuhan FOL, sehingga diameter koloni FOL lebih kecil dibandingkan dengan perlakuan. Hal ini juga menunjukkan bahwa selain khamir C. tropicalis, FOL juga mampu memanfaatkan gula sebagai sumber energi untuk pertumbuhannya. Glukosa dan sukrosa merupakan gula sederhana yang mudah dimanfaatkan oleh mikrob.

Hasil penelitian menunjukkan bahwa FOL mampu memanfaatkan gula-gula tersebut. Hal ini terlihat apabila nilai diameter FOL dibandingkan dengan kontrol PDA dekstros penuh nilai daya hambat yang didapat positif pada perlakuan penambahan gula tersebut dibeberapa konsentrasi uji. Demikian juga dengan gula D-xylose, salah satu penyusun utama gula $\mathrm{D}$-xylose adalah hemiselulosa yang merupakan molekul rendah dibandingkan dengan selulosa. Mikrooganisme seperti Trichoderma dan Fusarium memiliki aktivitas selulolitik yang tinggi (Chandel et al., 2007). Selulolitik adalah aktivitas mikrooganisme menghidrolisis atau memecah senyawa selulosa menjadi glukosa yang dapat dimanfaatkan untuk sumber energi. Diameter Fusarium lebih tinggi pada beberapa perlakuan dibandingkan dengan kontrol dikarenakan Fusarium memilki aktivitas selulolitik yang dapat mendegradasi gula D-xylose menjadi senyawa atau unit-unit glukosa yang lebih kecil (Anindyawati, 2010).

Gula trehalosa merupakan gula sederhana disakarida (Sedijani, 2014). Hasil penelitian menunjukkan bahwa penambahan gula trehalosa 2,5\% mampu menghambat pertumbuhan FOL. Hal ini menunjukkan bahwa khamir C. tropicalis diduga lebih mampu memanfaatkan gula trehalosa baik untuk pertumbuhannya maupun untuk meningkatkan antagonismenya.

Penambahan gula sebagai sumber nutrisi menyebabkan terjadinya mekanisme kompetisi ruang dan nutrisi sebagai akibat dari terbatasnya ketersediaan ruang dan nutrisi ketika khamir ditumbuhkan bersamaan dengan patogen (Hagagg \& Mohamed, 2007). Antagonisme khamir juga dapat bekerja melalui mekanisme antibiosis dengan menghasilkan senyawa antimikrob seperti enzim dan killer toxin (Janisiewicz \& Korsen, 2002). Menurut Saligkarias et al. (2002) penambahan sumber karbon juga dapat memengaruhi produksi senyawa antimikrob. Penambahan sumber karbon atau gula berpengaruh pada kemampuan penghambatan suatu mikrob antagonis terhadap patogen. Druvefors et al. (2004) melaporkan bahwa terbentuknya senyawa antifungal $P$. anomala dipengaruhi oleh kecepatan respon khamir tersebut terhadap ketersediaan oksigen dan gula.

Sumber karbon atau gula yang berbeda akan menunjukkan pengaruh yang berbeda pula terhadap kemampuan antagonisme suatu agens antagonis. Hasil penelitian ini berbeda dengan hasil pengujian pengaruh penambahan gula yang sama dengan konsentrasi yang sama terhadap kemampuan antagonisme $R$. minuta (Hartati dkk., 2018). Perlakuan penambahan gula glukosa, sukrosa, trehalosa, D-xylose, dan D-mannitol masing-masing dengan konsentrasi $1 \%$, 2,5\%, dan $5 \%$ mampu meningkatkan pertumbuhan koloni, kerapatan sel dan kemampuan antagonisme khamir $R$. minuta terhadap Colletotrichum acutatum (Hartati dkk., 2018). Hal ini menunjukkan bahwa jenis gula yang sama dengan konsentrasi yang sama belum tentu akan memberikan efek yang sama terhadap spesies khamir yang berbeda dan jamur patogen yang berbeda.

\section{SIMPULAN}

1. Gula trehalosa $1 \%$ dan D-mannitol $1 \%$ mampu meningkatkan pertumbuhan koloni dan kerapatan sel khamir C. tropicalis. Gula trehalosa $1 \%$ mampu meningkatkan kerapatan sel tertinggi khamir C. tropicalis yaitu sebesar $4,27 \times 10^{7}$.

2. Gula trehalosa 2,5\% mampu meningkatkan antagonisme khamir C. tropicalis terhadap FOL dengan daya hambat tertinggi sebesar 23,68\% dibandingkan kontrol.

\section{DAFTAR PUSTAKA}

Anindyawati, T. 2010. Potensi selulase dalam mendegradasi lignoselulosa limbah pertanian untuk pupuk organik. Berita Selulosa. 45(2): 70 - 77.

Barnett, JA, RW Payne, and D Yarrow. 2000. Yeast: Characteristics and Identification. $3^{\text {th }}$ ed. Cambridge University Press. Cambridge.

Chanchaichaovivat, A, P Ruenwongsa, B Panijpan. 2007. Screening and identification of yeast strains from fruits and vegetables: potential for biological control of postharvest chilli 
anthracnose (Colletotrichum Biological Control. 42: 326-335.

Chandel, AK, ES Chan, R Rudravaram, ML Narasu, LV Rao, and P Ravindra. 2007. Economics and environmental impact of bioetanol production technologies: An appraisal. Biotechnology and Molecular Biology Review. 2(1): 14-32.

Direktorat Jendral Hortikultura. 2018. Statistic of Horticulture Production on 2018. Direktorat Jendral Hortikultura. Kementerian Pertanian.

Druvefors, UÄ. 2004. Yeast biocontrol of grain spoilage moulds-mode of action of Pichia anomala. [Dissertation]. Swedish University of Agricultural Sciences. Swedia.

Fardiaz, S. 1992. Mikrobiologi Pengolahan Pangan. Departemen Pendidikan dan Kebudayan Direktorat Jenderal Pendidikan Tinggi Pusat Antar UniversitasPangan dan Gizi. Institut Pertanian Bogor. Bogor.

Haggag, WM, and HAA Mohamed. 2007. Biotechnological aspects of microorganisms used in plant biological control. AmericanEurasian Journal of Sustainable Agriculture. 1 (1): 7-12.

Hartati, S, S Wiyono, S Hidayat, and M Sinaga. 2017. Karakterisasi morfologi dan pemanfaatan gula oleh khamir antagonis patogen antraknosa. Jurnal Mikologi Indonesia. 1 (1): 28-37.

Hartati, S, WD Natawigena, N Istifadah, and SR Dewi. 2018. Penambahan gula untuk meningkatkan pertumbuhan dan antagonisme khamir Rhodotorula minuta terhadap Colletotrichum acutatum penyebab antraknosa cabai secara in-vitro. Agrikultura. 29 (2): 89-99.

Hartati, S. 2016. Khamir sebagai Agens Biokontrol Antraknosa (Colletotrichum acutatum J. H. Simmonds) pada Cabai Pascapanen. [Disertasi]. Sekolah Pascasarjana Institut Pertanian Bogor. Bogor.

Janisiewicz, WJ, and L Korsten. 2002. Biological control of postharvest diseases of fruits. Annual Review of Phytopathology. 40 (1): 411-441.

Janisiewicz, WJ. 1994. Enhancement of biocontrol of blue mold with the nutrient analog 2deoxy-D-glucose on apples and pears. Applied and Environmental Microbiology. 60(8): 2671-2676.
Kamel, SM, MM Ebtsam, and ON Massoud. 2016. Potentiality of some yeast species as biocontrol agents against Fusarium oxysporum f. sp. cucumerinum the causal agent of cucumber wilt. Egyptian Journal of Biological Pest Control. 26(2): 185-193.

Kementrian Pertanian. 2012. Daftar keputusan Menteri Pertanian. Tersedia online pada www.deptan.go.id. Diakses pada 15 Juni 2019.

Leepel, LA, S Sastra, R Puspitawati, and BM Bachtiar. 2009. Effect of xylitol with various concentration and duration on the growth of Candida albicans (in vitro study). Journal of Dentistry Indonesia. 16 (1): 72-76.

Nurhayati. 2010. Pengaruh waktu pemberian mikoriza vesikular arbuskular pertumbuhan tomat. Jurnal Agrivigor. 9(3):280-284.

Rahmawati, FC, E Kusdiyantini, and A Budiharjo. 2017. Isolasi dan identifikasi molekuler khamir dari molase serta kemampuannya dalam produksi etanol. Jurnal Akademika Biologi. 6(4): 89-98.

Saligkarias, ID, FT Gravanis, and HA Epton. 2002. Biological control of Botrytis cinerea on tomato plants by the use of epiphytic yeasts Candida guilliermondii strains 101 and US 7 and Candida oleophila strain I-182: II. A study on mode of action. Biological Control. 25(2): 151-161

Sedijani, P. 2014. Peran trehalose metabolisme sepanjang masa kehidupan tanaman. Jurnal Biologi Tropis. 14(2): 139-152.

Sharma, RR, D Singh, R Singh. 2009. Biological control of postharvest diseases of fruits and vegetables by microbial antagonists. Biological Control. 50: 205-221.

Shinohara, ML, A Correa, D Bell-Pedersen, JC Dunlap, and JJ Loros. 2002. Neurospora clock-controlled gene 9 (ccg-9) encodes trehalose synthase: circadian regulation of stress responses and development. Eukaryotic cell. 1(1): 33-43.

Sriram, S, and SR Poornachanddra. 2013. Biological control of postharvest mango fruit rot caused by Colletotrichum gloeosporioides and Diplodia natalensis with Candida tropicalis and Alcaligenes feacalis. Indian Phytopathology. 66(4): 375-380.

Susanna, T Chamzurni, dan A Pratama. 2010. Dosis dan frekuensi kascing untuk pengendalian 
penyakit layu fusarium pada tanaman tomat. Jurnal Floratek. 5:152-163.

Syukur, M, HE Saputra, dan R Hermanto. 2015. Bertanam Tomat di Musim Hujan. Penebar Swadaya. Jakarta.

Türker, M. 2014. Yeast biotechnology: Diversity and applications. Pp. 1-26 in Proceedings of 27th VH Yeast Conference, April 14th 15th, 2014, Istanbul. Advances in Science and Industrial Productions of Baker's Yeast. İstanbul.
Váchová, L, M Čáp, and Z Palková. 2012. Yeast colonies: a model for studies of aging, environmental adaptation, and longevity. Oxidative medicine and cellular longevity. 2012: 1-8.

Wilia, W, Widodo, dan S Wiyono. 2012. Potensi khamir untuk mengendalikan penyakit antraknosa (Colletotrichum acutatum L.) pada tanaman cabai. Bioplantae. 1(4):65-72. 